\title{
A Study on Phytochemicals and Mineral Content of Indigenous Red Rice of Assam, India
}

\author{
Tiluttama Mudoi ${ }^{1}$ and Priyanka Das ${ }^{2 *}$ \\ ${ }^{1}$ Coffee Quality Division, Central Coffee Research Institute, Bengaluru-560001, India \\ ${ }^{2}$ Department of Biochemistry and Agricultural Chemistry, \\ Assam Agricultural University, Jorhat-785013, India \\ *Corresponding author
}

\section{Keywords \\ Colored rice, Red rice, Germplasm, Total phenols, Total flavonoids, Anthocyanins, Antioxidant activity, Minerals \\ Article Info \\ Accepted: \\ 04 March 2019 \\ Available Online: \\ 10 April 2019}

\section{A B S T R A C T}

Considering nutraceutical potentiality of phytochemicals, a few indigenous red rice germplsams of Assam, India were analysed for various phytochemicals, antioxidant activities and a few mineral contents. Among the sixteen germplasm analysed in their brown form, the total phenol content, total flavonoid content, and the anthocyanin content per100 gm dry matter ranged from752.89 $\mathrm{mg} \pm 18.12$ ('Ranga Dariya') to $2223 \mathrm{mg} \pm 33.48$ ('Amana Bao'), $252.12 \pm 15.40 \mathrm{mg}$ ('Ixojoy') to $1000.75 \pm 86.93 \mathrm{mg}$ ('Dal Bao') and $76.05 \pm$ $0.32 \mu \mathrm{g}$ ('Kolaguni') to $159.42 \pm 15.97 \mu \mathrm{g}$ ('Betu'), respectively. For the polished form of rice, the same in $100 \mathrm{gm}$ dry matter ranged from76.51 mg \pm 1.46 in 'Ranga Dariya' to 1409 $\mathrm{mg} \pm 100.88$ in 'Kolaguni', from $32.09 \pm 7.17 \mathrm{mg}$ in 'Ranga Dariya' to $374.46 \pm 2.05 \mathrm{mg}$ in 'Negheribao' and from $17.91 \pm 5.08 \mu \mathrm{g}$ ('Biroi') to $115.42 \pm 11.72 \mu \mathrm{g}$ ('Hurupibao'), respectively. The antioxidant activities were observed to be the highest $96.00 \pm 0.26 \%$ in 'Negheribao' (for brown form of rice) and $86.35 \pm 3.88 \%$ in 'Kenekuabao' (for polished form of rice) and the lowest $81.54 \pm 0.23 \%$ in 'Betu'(for brown form of rice) and $59.65 \pm 4.64 \%$ in 'Ranga Dariya' (polished rice), respectively. In brown rice, on dry weight basis, the iron, zinc and manganese content ranged from 2.12-54.40 mg per $100 \mathrm{gm}, 2.42$ $\mathrm{mg}$ to $26.57 \mathrm{mg}$ per $100 \mathrm{gm}$ and $0.04 \mathrm{mg}$ per $100 \mathrm{gm}$ to $25.13 \mathrm{mg}$ per $100 \mathrm{gm}$, respectively. The study revealed some indigenous rice germplasm of Assam, India which are significant considering phenolic compounds and mineral content.

\section{Introduction}

Rice (Oryza sativa $\mathrm{L}$.) is the most important cereal worldwide. Traditionally, it has been the staple food and main source of income for more than $50 \%$ of the world's population. Besides being the main source of calories, rice is an important cereal because it has the highest digestibility, biological value and protein efficiency ratio among all cereal (Kaul, 1973). Rice starch mainly differs in amylose content; amylose molecule determines the grain's gelatinization temperature, pasting behavior and viscoelastic properties (Tavares et al., 2010) and has been an important component to be 
considered in quality breeding of rice (Zhang et al., 2007 and Bhattacharya, 2009).

Rice is generally consumed as white rice with the husk, bran, and germ removed. However, consumption of brown rice (hulled rice) is increasing in recent years, due to the increased awareness about its health benefits and good nutritional properties due to higher amounts of proteins, minerals and also phytochemicals (Tan et al., 2009 and Mohan et al., 2010). Whole grain consumption is associated with the prevention of chronic diseases, such as cancer and cardiovascular disease

Although, white rice is widely popular in South Eastern Asia, there are also some red, purple and black colored rice cultivars available. The color of rice results from the high content of anthocyanins located in the pericarp layers (Abdel-Aal and Hucl, 1999). Anthocyanin pigments have been reported to be highly effective in reducing cholesterol levels in the human body (Lee et al., 2008) and also due to aldose reductase inhibitory activities, they are beneficial for diabetic prevention (Yawadio et al., 2007). Colored rices are reported as potent sources of antioxidants and functional food because of its high polyphenols and anthocyanin content (Yawadio et al., 2007). Colored rice is more nutritious than white rice, as it is good source of fiber, vitamins, minerals, and several important amino acids (Itani et al., 2002). Attention is currently being given to the antioxidant and radical scavenging properties of colored rice cultivars because of their potential to provide and promote human health by reducing the concentration of reactive oxygen species and free radicals (Nam et al., 2006 and Oki et al., 2002).

Apart from genotypic differences, grain micronutrient content is also dependent on location (Rao et al., 2014). It was reported that that heavy metal concentrations in rice straw and grains were negatively correlated with soil $\mathrm{pH}$ value, but positively correlated with soil organic matter content, except grain $\mathrm{Pb}$ and $\mathrm{Zn}$ concentrations (Zeng et al., 2011). Bhuyan et al., 2014 reported that in Lakhimpur district of Assam, India, soils were strongly acidic to near neutral in reaction ( $\mathrm{pH} 4.60-6.61)$ with organic carbon (OC) content ranging from low to high (1.20$18.3 \mathrm{~g} \mathrm{~kg}^{-1}$ ) and diethylene tri amine penta acetic acid (DTPA) extractable Fe, $\mathrm{Zn}$, and $\mathrm{Mn}$ varied from 36.4 to $224.1,0.10$ to 1.68 , and 4.60 to $131.3 \mathrm{mg} \mathrm{kg}^{-1}$, respectively (Bhuyan et al., 2014). It was reported earlier (Neelamraju et al., 2012) that large genetic variation exists for grain iron and zinc in rice germplasm including wild species and deep water rices. They reported that 'Madhukar' and 'Jalmagna' are deep-water rice varieties with high grain iron and zinc and overall, $\mathrm{Fe}$ concentration ranged from 0.2 to $224 \mathrm{ppm}$ (or 0.02 to $22.4 \mathrm{mg}$ per $100 \mathrm{gm}$ ) and $\mathrm{Zn}$ concentration from 0.4 to $104 \mathrm{ppm}$ (or 0.04 to $10.4 \mathrm{mg}$ per $100 \mathrm{gm})$.

Several varieties of colored rice, particularly red and black rice, have been cultivated in North Eastern part of India. Rice is principal food crop of the region and is extensively cultivated in upland, lowland and deepwater conditions. Among these, the state Assam is particularly rich in rice germplasm with extreme physicochemical properties. Traditionally, it has been the staple food and main source of income for the people of Assam.The state has its climatic and physiographic features favourable for rice cultivation and the crop is grown in a wide range of agro-ecological situations. The release of high yielding varieties replaces the traditional landraces, which leads to gradual erosion of the rice genetic diversity. It was found that the indigenous varieties were relatively superior with respect to demand, resistance to pest and diseases and eating 
quality, although their yield is low as compared to commercial white rice varieties. But there is important point that these varieties are invariably grown organically. These varieties are yet to be investigated for their nutritional and phytochemical properties. Therefore, the present study was undertaken to find out the phyto-chemical composition of a few indigenous colored rice cultivars of Assam. Earlier, the proximate composition and amylose content of some indigenous coloured rice germplasm of Assam, India was reported by the present authors (Mudoi and Das, 2018).

\section{Materials and Methods}

\section{Collection of red rice samples}

The details of indigenous colored rice germplasm, analysed in the present study and the place of collection are mentioned at Table 1. The non-pigmented variety 'Ranjit' was collected from Assam Agricultural University, Jorhat, Assam, India.

\section{Processing of rice grains}

Rice grains were de-husked using a de-husker (Satake Corporation, Hiroshima, Japan) and then polished (4\%) using a polisher (Satake Corporation, Hioroshima, Japan). The brown and polished rice grains were ground to flour and used for further analysis.

\section{Extraction of rice samples for total phenols, total flavonoid content and antioxidant activity}

The rice flour $(1.5 \mathrm{~g})$ was extracted $(1: 20 \mathrm{w} / \mathrm{v})$ at room temperature with $85 \%$ aqueous methanol under agitation for $30 \mathrm{~min}$ using a magnetic stirrer. The mixtures were centrifuged at $2500 \mathrm{~g}$ for $10 \mathrm{~min}$ and the supernatants were collected. The residues were re-extracted twice under the same conditions, resulting finally in $50 \mathrm{ml}$ crude extract.

\section{Determination of total phenolic content (TPC)}

The TPC of extracts was determined using the Folin-Ciocalteu reagent (Singleton et al., 1999). Extract $(120 \mu \mathrm{l})$ was added to $600 \mu \mathrm{l}$ of freshly diluted (10-fold) Folin-Ciocalteu reagent. $7.5 \%$ Sodium carbonate solution (980 $\mu \mathrm{l})$ was added to the mixture after $2 \mathrm{~min}$ reaction time. The absorbance of the resulting blue colour was measured at $760 \mathrm{~nm}$ against a blank after 5 min of reaction time at $50{ }^{0} \mathrm{C}$. Catechol was used as standard and TPC was expressed as mg catechol equivalent per $100 \mathrm{~g}$ dry sample.

\section{Determination of total flavonoid content}

The total flavonoid content was measured by colorimetric method as described previously (Wu and $\mathrm{Ng}, 2008$ ). Briefly, $0.5 \mathrm{ml}$ of sample extract in methanol was mixed with $2 \mathrm{ml}$ of deionized water, $0.15 \mathrm{ml}$ of $5 \%$ sodium nitrite and $0.15 \mathrm{ml}$ of $10 \%$ aluminium chloride, followed by reaction time of $6 \mathrm{~min}$. Then, $4 \%$ $\mathrm{NaOH}(2 \mathrm{ml})$ was added to the mixture and mixed well. After $15 \mathrm{~min}$ at room temperature, the absorbance of the mixture was measured at $510 \mathrm{~nm}$. All values were expressed as $\mathrm{mg}$ quercetin equivalent (QE) per 100 gm dry wt.

\section{Determination of anthocyanin content}

To determine total anthocyanins, the spectrophotometric method reported by Abdel-Aal and Hucl (1999) was employed. The anthocyanins were extracted using acidified methanol $(0.1 \mathrm{M} \mathrm{HCl} /$ methanol $85: 15, \mathrm{v} / \mathrm{v})$ with a solvent to sample ratio of $10: 1$, at room temperature for $30 \mathrm{~min}$ on a magnetic stirrer and then centrifuged and the supernatants were collected. The residues 
were re-extracted twice under the same conditions, and the supernatants were combined and kept in the dark and at $4^{\circ} \mathrm{C}$ until further analyzed. The absorbance was measured at $525 \mathrm{~nm}$ using a UV-visible spectrophotometer against a reagent blank. Cyanidin-3-chloride was used to prepare the standard calibration curve. Total anthocyanin contents in the red rice samples were expressed as $\mu \mathrm{g}$ Cyanidin-3-chloride equivalents per $100 \mathrm{~g}$ dry weight of samples.

\section{Determination of 2, 2-diphenyl-1-picryl hydrazyl (DPPH) radical scavenging activity}

The free radical scavenging activity of the methanol extract was measured following a previously reported procedure (Brandwilliams et al., 1995), using the stable 2,2diphenyl-1-picryl hydrazyl radical (DPPH•) An aliquot of $0.3 \mathrm{ml}$ of a diluted methanolic extract (2 times) was vigorously mixed with $1.5 \mathrm{ml}$ of freshly prepared $0.004 \% \mathrm{DPPH}$ in methanol and held in the dark for $30 \mathrm{~min}$ at room temperature. The absorbance was then read at $517 \mathrm{~nm}$ against blank (only methanol). An equal mixture of methanol and $0.004 \%$ DPPH in methanol was used as control. DPPH free radical scavenging ability was calculated by using the following formula:

Scavenging activity (\%, dry basis)

$=$ (absorbance of control - absorbance of sample)/ (absorbance of control) $\times 100$

\section{Mineral content}

The mineral contents in the powdered rice samples were determined using the methods described in AOAC (1997). The ash obtained as per AOAC method, 1997 was dissolved in dilute $\mathrm{HCl}(1: 1)$ on a water bath at $100^{\circ} \mathrm{C}$ and the mixture was evaporated to dryness. $4 \mathrm{ml}$ of $\mathrm{HCl}$ and $2 \mathrm{ml}$ of glass distilled water were added, warmed and the acid soluble portion obtained after filtration was made up to 100 ml with glass distilled water. This solution was used for estimation of $\mathrm{Fe}, \mathrm{Zn}$ and $\mathrm{Mn}$ in colored rice samples by atomic absorption spectrometer.

\section{Results and Discussion}

\section{Total phenol content (TPC)}

TPC of the investigated rice germplasms is presented in Table 2. The TPC content of red rice germplasms was compared with nonpigmented rice variety, 'Ranjit' which is commercially cultivated in Assam. All the brown form of pigmented rice samples contained higher amount of phenolic compound than non-pigmented brown form of rice 'Ranjit' (232.94 $\pm 11.45 \mathrm{mg}$, Table 2). TPC of brown form of rice samples (catechol equivalents per $100 \mathrm{~g}$, dry wt basis) ranged from $752.89 \mathrm{mg}$ in 'Ranga Dariya' to $2223 \mathrm{mg}$ in 'Amana Bao'. TPC of polished rice samples (catechol equivalents per $100 \mathrm{~g}$, dry basis) varied from $76.51 \mathrm{mg}$ in 'Ranga Dariya' to -1409 mg in 'Kolaguni'. There was loss of TPC in polished samples in comparison to their respective brown rice after polishing (4\%). Reddy et al., 2017 also reported reduction of $85.54 \%$ to $89.97 \%$ TPC in pigmented rice by $9 \%$ polishing treatment and 7.75-10.55 mg/g TPC in brown form of pigmented rice varieties.

For polished form of rice, the detection of lower amount of total phenols in some of the pigmented varieties than the same in nonpigmented 'Ranjit' (162.98 \pm 8.97$)$ might indicate the presence of phenolic compound mainly on outer layer of grains which was lost on polishing. The phenolic compounds in whole rice grain were reported to be from 108.1 to $1244.9 \mathrm{mg}$ gallic acid equivalent/100 $\mathrm{g}$ depending on color of the grain (Shen et al., 2009). Chen et al., 2012 also reported that the total phenolic compounds in red rice ranged from $460.32-725.69 \mathrm{mg} / 100 \mathrm{~g}$. 


\section{Total flavonoid content (TFC)}

Total flavonoid content (mg quercetin equivalent per $100 \mathrm{gm}$ rice samples, on dry $\mathrm{wt}$ basis) was significantly different among the red rice germplasm (Table 2). In the brown form of rice, the highest content of flavonoid was found in 'Dal bao' $(1000.75 \pm 86.93 \mathrm{mg})$ and the lowest in 'Ixojoy' $(252.12 \pm 15.40 \mathrm{mg})$. There was decrease in TFC in polished rice samples as compared to their respective brown rice samples. In the polished rice, the TFC varied from $32.09 \pm 7.17 \mathrm{mg}$ in 'Ranga Dariya' to $374.46 \pm 2.05 \mathrm{mg}$ in 'Negheribao'. However, the same for the non-pigmented variety 'Ranjit' was found to be $109.81 \pm$ $7.15 \mathrm{mg}$ and $66.93 \pm 10.01 \mathrm{mg}$ for brown and polished form, respectively.

Shen et al., 2009 reported the TFC in whole rice (white, red and black) to be in the range from 88.6 to $286.3 \mathrm{mg}$ rutin equivalent $/ 100 \mathrm{~g}$ (Shen et al., 2009). The present study also indicated that the brown form of pigmented rice varieties contained a higher value of TFC than the brown form of non-pigmented rice variety 'Ranjit' (109.81 $\pm 7.15 \mathrm{mg})$. Reddy et al., 2017 reported the TFC in pigmented rice varieties, which ranged from 3.25 to 3.90 mg/g. Ghasemzadeh et al., 2018 reported higher flavonoid content in red rice bran (238.76- $457.00 \mathrm{mg}$ QE/100 g dry matter, respectively) than brown rice bran (105.7$240.88 \mathrm{mg}$ QE/100 g dry matter, respectively).

\section{Anthocyanin content}

The anthocyanin content in different red rice germplasms of Assam is presented in Table 2. Anthocyanin content in brown rice sample varied from 76.05-159.42 ug cyaniding choride equivalent per 100 gm dry wt. For brown rice, the highest content of anthocyanin was found in 'Betu' (159.42 $\pm 15.97 \mathrm{ug})$ with the lowest in 'Kolaguni' (76.05 $0.32 \mathrm{ug})$. In polished rice, anthocyanin content varied from $17.91 \pm 5.08$ ug to $115.42 \pm 11.72$ ug cyanidin chloride equivalents per $100 \mathrm{gm}$. In comparison to brown form, the loss of anthocyanin content in polished rice sample occurred up to $88 \%$ in 'Biroi'. However, in some of the samples, the decrease in anthocyanin content in polished samples than those of brown, was not significant, which represented more uniform distribution of the pigment in the grain. Saikia et al., 2012 reported higher anthocyanin content (35.87 $\mathrm{mg}$ per $100 \mathrm{gm}$ ) in black rice (polished) cultivar from Manipur, 'Poreiton Chakhao 'than red rice, 'Chak-hao-amubi' (1.81 mg per 100gm). A higher level of total anthocyanin content (TAC) than the result of the present finding was reported by Sompong et al., 2011, which ranged from 0.3 to $1.4 \mathrm{mg}$ and109.5-256.6 mg/100 $\mathrm{g}$ in red and black rice varieties, respectively.

\section{DPPH free radical scavenging activity}

DPPH free radical scavenging activity (Table 3 ) in brown rice samples ranged from $81.54 \pm 0.23-96.00 \pm 0.26 \%$. 'Negheribao' showed the highest antioxidant activity which might be due to presence of higher amount of total phenols, total flavonoids and anthocyanins. In polished rice sample, DPPH scavenging activity varied from $59.65 \pm 4.64$ to $86.35 \pm 3.88 \%$. It was reported that the pigmented rice varieties showed high DPPH (2, 2-diphenyl-1-picrylhydrazyl) radical scavenging activity $(94.19 \%$ and $96.43 \%$ in polished rice sample) (Saikia et al., 2012). Finocchiaro et al., $(2007,2010)$ reported that the total antioxidant capacity of red-grained rice genotypes were three times higher than those of white-grained rice genotypes. DPPH activity in brown form of pigmented rice varieties ranged from $84.77 \%$ to $92.67 \%$ as reported by Reddy et al., 2017. After polishing, the lowest DPPH activity was observed with $6.11-6.55 \%$. Previously, it was 
reported (Ghasemzadeh et al., 2015 and Djeridane et al., 2006) that the concentration of total phenolics and flavonoids in rice grains were positively correlated with the antioxidant activity. Oki et al., (2002) reported that in red pericarp grains, a strong correlation between antioxidant activity and the content of proanthocyanidins was observed; however, in the case of black pericarp grains, the correlation was dependent on the content of anthocyanins. These results suggest that phenolic compounds were primarily responsible for the antioxidant activity of rice grains.

\section{Mineral content}

Minerals play an important role in human health and are required to maintain a balanced diet, which is important for conserving all regular metabolic functions. In the present study, on dry weight basis, the iron content in brown form of rice samples ranged from 2.12$54.40 \mathrm{mg}$ per $100 \mathrm{gm}$ (Table 4). The autumn rice 'Rongasokua' (brown form) contained the highest (54.40 mg per 100 gm dry wt) amount of iron. Detection of higher iron content in some varieties might be related to low soil $\mathrm{pH}$ of the locality where the variety was grown. Bhuyan et al., (2014) reported that in Lakhimpur district of Assam, soils were strongly acidic to near neutral in reaction ( $\mathrm{pH} 4.60-6.61)$. The wet land rice in many humid tropical regions of Asia, Africa, and South America are affected by iron toxicity, which mainly occur due to increase in $\mathrm{Fe}$ (II) concentration in soil solution resulting from drop of redox potential arising from anaerobic situations in submerged rice fields. The high quantity of ferrous ions in the soil solution upsets the mineral element balance in rice plants and affects its growth. A field experiment was carried ${ }^{32}$ out in acidic laterite soil $(\mathrm{pH} 5.1)$ having $400 \mathrm{mg} \mathrm{kg}^{-1}$ diethylene tri amine penta acetic acid (DTPA) extractable $\mathrm{Fe}$ for developing strategies to combat Fe toxicity and to study Fe, $\mathrm{Zn}$, and Mn nutrition in rice. Among the treatments, the highest Fe content (124 mg per kg or 12. 4 $\mathrm{mg}$ per $100 \mathrm{gm}$ in grain) was recorded in control for all cultivars. They also reported the $\mathrm{Zn}$ and $\mathrm{Mn}$ content of grain to be 35 and $59 \mathrm{mg}$ per $\mathrm{kg}$ (or 3.5 and 5.9mg per $100 \mathrm{gm}$ ).

Table.1 Indigenous red rice germplasms collected from different regions of Assam

\begin{tabular}{|c|l|l|c|}
\hline SI No. & $\begin{array}{l}\text { Names of } \\
\text { germplasm }\end{array}$ & Place of collection & Type of rice \\
\hline $\mathbf{1}$ & Amana Bao & North Lakhimpur, Assam & Deep water rice \\
\hline $\mathbf{2}$ & Betu & Majuli, Assam & Autumn rice \\
\hline $\mathbf{3}$ & Biroi & North Lakhimpur, Assam & Winter rice \\
\hline $\mathbf{4}$ & Bogaguni & North Lakhimpur, Assam & Autumn rice \\
\hline $\mathbf{5}$ & Burali & North Lakhimpur, Assam & Autumn rice \\
\hline $\mathbf{6}$ & Dal Bao & North Lakhimpur, Assam & Deep water rice \\
\hline $\mathbf{7}$ & Hurupi Bao & North Lakhimpur, Assam & Deep water rice \\
\hline $\mathbf{8}$ & Ixojoy & North Lakhimpur, Assam & Autumn rice \\
\hline $\mathbf{9}$ & Jul Bao & North Lakhimpur, Assam & Deep water rice \\
\hline $\mathbf{1 0}$ & Kenkua Bao & North Lakhimpur, Assam & Deep water rice \\
\hline $\mathbf{1 1}$ & Kolaguni & North Lakhimpur, Assam & Autumn rice \\
\hline $\mathbf{1 2}$ & Kopouguni & North Lakhimpur, Assam & Autumn rice \\
\hline $\mathbf{1 3}$ & Kotia Bao & North Lakhimpur, Assam & Deep water rice \\
\hline $\mathbf{1 4}$ & Negheri Bao & North Lakhimpur, Assam & Deep water rice \\
\hline $\mathbf{1 5}$ & Ronga Chokua & North Lakhimpur, Assam & Autumn rice \\
\hline $\mathbf{1 6}$ & Ronga Dariya & North Lakhimpur, Assam & Autumn rice \\
\hline
\end{tabular}


Table.2 Total polyphenol, flavonoid content and anthocyanin content of different red rice germplasms of Assam

\begin{tabular}{|c|c|c|c|c|c|c|c|}
\hline \multirow[t]{2}{*}{ SI No } & \multirow[t]{2}{*}{ Name of variety } & \multicolumn{2}{|c|}{$\begin{array}{l}\text { Total phenol content(mg catechol } \\
\text { equivalents per } 100 \mathrm{~g})\end{array}$} & \multicolumn{2}{|c|}{$\begin{array}{l}\text { Total flavonoid content (mg } \\
\text { quercetin equivalents per } 100 \\
\text { gm dry wt) }\end{array}$} & \multicolumn{2}{|c|}{$\begin{array}{l}\text { Anthocyanin content (ug } \\
\text { cyaniding choride equivalent } \\
\text { per } 100 \text { gm dry wt) }\end{array}$} \\
\hline & & Brown rice & Polished rice & Brown rice & Polished rice & Brown rice & Polished rice \\
\hline 1 & Amana bao & $2223.68 \pm 33.48$ & $547.03 \pm 25.09$ & $766.65 \pm 11.45$ & $216.84 \pm 2.07$ & $96.75 \pm 9.87$ & $79.481 \pm 1.12$ \\
\hline 2 & Betu & $1136.98 \pm 53.68$ & $94.67 \pm 7.27$ & $478.10 \pm 41.53$ & $41.63 \pm 25.57$ & $159.42 \pm 15.97$ & $66.93 \pm 9.915$ \\
\hline 3 & Biroi & $1462.27 \pm 56.58$ & $289.19 \pm 17.25$ & $495.14 \pm 40.74$ & $137.92 \pm 12.90$ & $155.26 \pm 48.48$ & $17.91 \pm 5.08$ \\
\hline 5 & Burali & $1986.09 \pm 31.51$ & $298.28 \pm 5.72$ & $778.67 \pm 39.62$ & $115.66 \pm 5.69$ & $107.93 \pm 19.263$ & $40.46 \pm 24.57$ \\
\hline 6 & Dal bao & $2215.73 \pm 67.50$ & $263.50 \pm 7.12$ & $1000.75 \pm 86.9$ & $73.62 \pm 18.19$ & $112 \pm 11.12$ & $48.26 \pm 19.48$ \\
\hline 7 & Hurupibao & $1283.23 \pm 47.89$ & $142.66 \pm 20.97$ & $443.65 \pm 25.47$ & $33.79 \pm 6.54$ & $144.73 \pm 1.24$ & $103.63 \pm 16.87$ \\
\hline 8 & Ixojoy & $762.52 \pm 76.83$ & $165.72 \pm 9.46$ & $252.12 \pm 15.4$ & $125.82 \pm 19.91$ & $95.26 \pm 7.51$ & $52.14 \pm 18.52$ \\
\hline 9 & Jul bao & $1145.06 \pm 33.59-$ & $933.89 \pm 34.12$ & $466.10 \pm 67.93$ & $248.58 \pm 58.36$ & $80.31 \pm 0.35$ & $78.61 \pm 0.36$ \\
\hline 13 & Kotiabao & $897.53 \pm 172.52$ & $79.45 \pm 14.63$ & $372.07 \pm 51.95$ & $37.28 \pm 14.39$ & $128.13 \pm 18.26$ & $84.73 \pm 56.83$ \\
\hline 14 & Negheribao & $1740.38 \pm 87.51$ & $924.51 \pm 93.63$ & $617.05 \pm 20.08$ & $374.46 \pm 2.05$ & $148.55 \pm 31.74$ & $61.60 \pm 9.72$ \\
\hline 15 & RangaDariya & $752.89 \pm 18.12$ & $76.51 \pm 1.46$ & $394.01 \pm 21.34$ & $32.09 \pm 7.17$ & $85.09 \pm 7.87$ & $39.23 \pm 24.19$ \\
\hline 16 & Rongasokua & $1534.52 \pm 143.45$ & $247.18 \pm 1.19$ & $387 \pm 23.15$ & $80.97 \pm 35.37$ & $77.61 \pm 1.34$ & $46.43 \pm 22.78$ \\
\hline 17 & $\begin{array}{l}\text { Ranjit (Non } \\
\text { pigmented rice) }\end{array}$ & $232.94 \pm 11.45$ & $162.98 \pm 8.97$ & $109.81 \pm 7.15$ & $66.93 \pm 10.01$ & - & - \\
\hline
\end{tabular}


Table.3 DPPH free radical scavenging activity of different red rice germplasm of Assam

\begin{tabular}{|r|l|c|c|}
\hline \multirow{2}{*}{$\begin{array}{l}\text { Sl } \\
\text { No }\end{array}$} & Name of variety & \multicolumn{2}{|c|}{ DPPH free radical scavenging activity } \\
\cline { 2 - 4 } & & Brown rice & Polished rice \\
\hline $\mathbf{1}$ & Amana bao & $92.80 \pm 2.05$ & $82.05 \pm 0.36$ \\
\hline $\mathbf{2}$ & Betu & $81.54 \pm 0.23$ & $73.74 \pm 2.29$ \\
\hline $\mathbf{3}$ & Biroi & $95.57 \pm 0.14$ & $84.23 \pm 0.16$ \\
\hline $\mathbf{4}$ & Bogaguni & $94.51 \pm 0.05$ & $85.12 \pm 2.05$ \\
\hline $\mathbf{5}$ & Burali & $88.61 \pm 2.69$ & $85.30 \pm 0.04$ \\
\hline $\mathbf{6}$ & Dal bao & $94.63 \pm 0.05$ & $82.33 \pm 1.77$ \\
\hline $\mathbf{7}$ & Hurupibao & $84.65 \pm 3.14$ & $84.14 \pm 0.00$ \\
\hline $\mathbf{8}$ & Ixojoy & $83.97 \pm 0.78$ & $82.88 \pm 1.44$ \\
\hline $\mathbf{9}$ & Jul bao & $82.62 \pm 0.42$ & $82.96 \pm 0.20$ \\
\hline $\mathbf{1 0}$ & Kenkuabao & $94.82 \pm 0.34$ & $86.35 \pm 3.88$ \\
\hline $\mathbf{1 1}$ & Kolaguni & $81.62 \pm 0.20$ & $84.00 \pm 0.25$ \\
\hline $\mathbf{1 2}$ & Kopouguni & $84.51 \pm 0.47$ & $82.22 \pm 0.05$ \\
\hline $\mathbf{1 3}$ & Kotiabao & $84.17 \pm 0.29$ & $81.55 \pm 1.69$ \\
\hline $\mathbf{1 4}$ & Negheribao & $96.00 \pm 0.26$ & $82.37 \pm 0.24$ \\
\hline $\mathbf{1 5}$ & Ranga Dariya & $83.32 \pm 0.32$ & $59.65 \pm 4.64$ \\
\hline $\mathbf{1 6}$ & Rongasokua & $83.38 \pm 0.40$ & $83.07 \pm 0.09$ \\
\hline
\end{tabular}

Table.4 Mineral content of red rice germplasm (brown form) of Assam

\begin{tabular}{|l|l|c|c|c|}
\hline SI No & Variety & $\begin{array}{c}\text { Fe content } \\
(\mathbf{m g} / \mathbf{1 0 0 g m})\end{array}$ & $\begin{array}{c}\text { Zn content } \\
(\mathbf{m g} / \mathbf{1 0 0 g m})\end{array}$ & $\begin{array}{c}\text { Mn content } \\
(\mathbf{m g} / \mathbf{1 0 0 g m})\end{array}$ \\
\hline $\mathbf{1}$ & Amana bao & 2.12 & 2.42 & ND \\
\hline $\mathbf{2}$ & Betu & 3.54 & 5.34 & ND \\
\hline $\mathbf{3}$ & Biroi & 3.87 & 6.31 & 3.72 \\
\hline $\mathbf{4}$ & Bogaguni & 5.55 & 12.16 & 0.65 \\
\hline $\mathbf{5}$ & Burali & 3.43 & 8.92 & 0.04 \\
\hline $\mathbf{6}$ & Dal bao & 3.79 & 6.65 & ND \\
\hline $\mathbf{7}$ & Hurupibao & 16.67 & 10.63 & ND \\
\hline $\mathbf{8}$ & Ixojoy & 6.09 & 5.22 & 2.81 \\
\hline $\mathbf{9}$ & Jul bao & 6.20 & 7.49 & ND \\
\hline $\mathbf{1 0}$ & Kenkuabao & 5.69 & 5.42 & 4.95 \\
\hline $\mathbf{1 1}$ & Kolaguni & 16.17 & 24.94 & 25.13 \\
\hline $\mathbf{1 2}$ & Kopouguni & 8.72 & 7.67 & ND \\
\hline $\mathbf{1 3}$ & Kotiabao & 9.81 & 26.57 & ND \\
\hline $\mathbf{1 4}$ & Negheribao & 5.70 & 6.01 & 5.79 \\
\hline $\mathbf{1 5}$ & Rangadariya & 3.28 & 8.64 & 3.75 \\
\hline $\mathbf{1 6}$ & Rongasokua & 54.40 & 9.99 & ND \\
\hline
\end{tabular}


However, Yodmanee et al., (2011) reported the iron content in pigmented brown rice samples to be $0.91-1.66 \mathrm{mg} / 100 \mathrm{~g}$. Low mineral (iron and $\mathrm{Zn}$ ) content reported for some of the rice germplasm of India might be due to expression in polished (up to $10 \%$ ) form (Rao et al., 2014). The micronutrients are lost during polishing (Sellappan et al., 2009). Thus rice grain iron content will also vary with degree of milling / polishing (Reddy et al., 2018).

In the present study, the manganese was not detected in some of the rice germplasm in brown form. On dry weight basis, the manganese content was found to be the highest in brown form of autumn rice 'Kolaguni' (25.13 mg per $100 \mathrm{gm}$ ). The zinc content in brown rice was observed to be 2.42 $\mathrm{mg}$ in 'Amana bao' to $26.57 \mathrm{mg}$ per $100 \mathrm{gm}$ in 'Kotiabao'. Anuradha et al., (2012) analyzed brown rice of 126 accessions of rice genotypes for $\mathrm{Fe}$ and $\mathrm{Zn}$ concentration. Iron concentration ranged from $6.2 \mathrm{ppm}$ to 71.6 ppm (or $0.62 \mathrm{mg}$ to $7.16 \mathrm{mg}$ per $100 \mathrm{gm}$ ) and zinc from $26.2 \mathrm{ppm}$ to $67.3 \mathrm{ppm}$ (or 2.62 to $6.73 \mathrm{mg}$ per $100 \mathrm{gm})$. It was reported that in 'Madhukar' and 'Jalmagna', two deep-water rice varieties of India, the grain iron concentration ranged from 0.2 to $224 \mathrm{ppm}$ (or 0.02 to $22.4 \mathrm{mg}$ per $100 \mathrm{gm})$ and zinc concentration from 0.4 to $104 \mathrm{ppm}$ ( or 0.04 to $10.4 \mathrm{mg}$ per $100 \mathrm{gm}$ ) (Neelamraju et al., 2012).

In conclusion, the present study reveals that the pigmented rice germplasm of Assam, India are rich source of phenolic compounds, particularly flavonoids among which the anthocyanins are not the major one. Most of the phenolic compounds can be retained at four percent polishing rate. The study also reveals that some of the indigenous pigmented rice germplasm (brown form) are rich in iron, zinc and manganese, which might be due to low $\mathrm{pH}$ of soil and growing situation. These varieties can be considered by the plant breeders for bio fortification program of rice. There is scope to study the profiles of various phenolic compounds and the micronutrients present in abundantly available indigenous pigmented rice germplasm of Assam, India.

Conflict of interest: Authors declare that they have no conflict of interest.

\section{Acknowledgement}

The first author is grateful to Department of Biotechnology, Ministry of Science and Technology, Govt of India for offering her DBT Research Associate ship and funding to carry the project work.

\section{References}

Abdel-Aal, E. S. M., and Hucl, P. 1999. A rapid method for quantifying total anthocyanins in blue aleurone and purple pericarp wheats. Cereal Chemistry. 76: 350-354.

Anuradha, K., Agarwal, S., Batchu, A. K., Babu, A. P., Mallikarjuna Swamy, B. P., Longvah, T. and Sarla, N. 2012. Evaluating rice germplasm for iron and zinc concentration in brown rice and seed dimensions. Journal of Phytology. 4(1): 19-25.

AOAC. 1997. Official methods of analysis of Association of Official Analytical Chemists. 16th edn. Washington, USA.

Bhattacharya, K. R. 2009. Physicochemical Basis of Eating Quality of Rice. Cereal Food World, 54(1): 18-28.

Bhuyan, N., Barua, N. G., Borah, D. K., Bhattacharyya, D. and Basumatari, A. 2014. Georeferenced micronutrient status in soils of Lakhimpur district of Assam. Journal of the Indian Society of Soil Science, 62(2): 102-107.

Brand-williams, W., Cuvelier, M.E. and 
Berset, C. 1995. Use of free radical method to evaluate antioxidant activity. Lebensmittel Wissenschaft and Technologie. 28: 25-30.

Chen, X. Q., Nagao, N., Itani, J., Irifune, K. 2012. Anti-oxidative analysis and identification and quantification of anthocyanin pigments in different colored rice. FoodChem. 135: 27832788.

Djeridane, A., Yousfi, M., Nadjemi, B., Boutassouna, D., Stocker, P., Vidal, N. 2006. Antioxidant activity of some Algerian medicinal plants extracts containing phenolic compounds. Food Chem. 97(4): 654-660.

Finocchiaro, F., Ferrari, B., Gianinetti, A. 2010. A study of biodiversity of flavonoid content in the rice caryopsis evidencing simultaneous accumulation of anthocyanins and proanthocyanidins in a black-grained genotype. Journal of Cereal Science. 51: 28-34.

Finocchiaro, F., Ferrari, B., Gianinetti, A., Dall'Asta, C., Galaverna, G., Scazzina, F. 2007. Characterization of antioxidant compounds of red and white rice and changes in total antioxidant capacity during processing. Molecular Nutrition \& Food Research. 51: 1006-1019.

Ghasemzadeh, A., Jaafar, H. Z., Rahmat, A. 2015. Phytochemical constituents and biological activities of different extracts of Strobilanthes crispus (L.) Bremek leaves grown in different locations of Malaysia. BMC complement Altern Med., 15(1): 422.

Ghasemzadeh, A., Karbalaii, M. T., Jaafar, H. Z. E., Rahmat, A. 2018. Phytochemical constituents, antioxidant activity, and antiproliferative properties of black, red, and brown rice bran. Chem Cent J. 12: 17.

Itani, T., Tamaki, M., Arai, E., Horino, T. 2002. Distribution of amylase, nitrogen, and minerals in rice kernels with various characters. Journal of Agricultural and Food Chemistry. 50: 5326-5332.

Kaul, A. K. 1973. Nuclear techniques for seed protein improvement. LA.E.A., Vienna, p. 64.

Lee, J. C., Kim, J. D., Hsieh, F. H., Eun, J. B. 2008. Production of black rice cake using ground black rice and medium-grain brown rice. International Journal of Food Science and Technology, 2008, 43(6), 1078-1082.

Mohan, B. H., Malleshi, N.G. and Koseki, T., Physic-Chemical Characteristics and Non-Starch Polysaccharide Contents of Indica and Japonica Brown Rice and Their Malts. Food Science and Technology, 2010, 43(5), 784-791.

Mudoi, T. and Das, P., Nutritional composition of traditional colored rice cultivars of Assam, India. Bull. Env.Pharmacol. Life Sci., 2018, 7(7), 10-14.

Nam, S.H., Choi, S.P., Kang, M.Y., Koh, H.J., Kozukue, N. and Friedman, M., Antioxidative activities of bran extracts from twenty one pigmented rice cultivars. Food Chemistry, 2006, 94, 613-620.

Neelamraju, S., Mallikarjuna Swamy, B. P., Kaladhar, K., Anuradha, K., Venkateshwar Rao, Y., Batchu, A. K., Agarwal, S., Babu, A. P., Sudhakar, T., Sreenu, K., Longvah, T., Surekha, K., Rao, K. V., Ashoka Reddy, G., Roja, T. V., Kiranmayi, S. L., Radhika, K., Manorama, K., Cheralu, C. and Viraktamath, B. C., Increasing iron and zinc in rice grains using deep water rices and wild species-identifying genomic segments and candidate genes. Quality Assurance and Safety of Crops \& Foods, 2012, 4(3), 138.

Oki, T., Masuda, M., Kobayashi, M., Nishiba, Y., Furuta, S., Suda, I. and Sato, T., Polymeric procyanidins as radical- 
scavenging components in red-hulled rice. JAgric Food Chem., 2002, 50(26), 7524-7529.

Rao, D. S., Madhu Babu, P., Swarnalatha, P., Kota, S., Bhadana, V. P., Varaprasad, G.S., Surekha, K., Neeraja, C.N. and Babu, V. R., Assessment of Grain Zinc and Iron Variability in Rice Germplasm using Energy Dispersive X-ray Fluorescence Spectrophotometer (ED XRF). Journal of Rice Research, 2014, 7(1 \& 2), 45-52.

Reddy, C. K., Kimi, L., Haripriya, S. and Kang, N., Effects of Polishing on Proximate Composition, PhysicoChemical Characteristics, Mineral Composition and Antioxidant Properties of Pigmented Rice. Rice Science, 2017, 24(5), 241-252.

Reddy, M., Turaidar, V., Krupa, K. N., Ramachandra, A., Subhash Bharani, S., Dalawai, N., Enhancement of Iron and Zinc in Rice Grain through Biofortification Approach. Int.J.Curr.Microbiol.App.Sci., 2018, 7, 628-637.

Saikia, S., Dutta, H., Saikia, D. and Mahanta, C. L., Quality characterization and estimation of phytochemical content capacity of aromatic pigmented and non-pigmented rice varieties. Food Res Int., 2012, 46(1), 334-340.

Sellappan, K., Datta, K., Parkhi, V., Datta, S. K. 2009. Rice caryopsis structure in relation to distribution of micronutrients (iron, zinc, b-carotene) of rice cultivars including transgenic indica rice. Pl. Sci. 177: 557-562.

Shahid, M., Nayak, A. K., Shukla, A. K., Tripathi, R., Kumar, A., Raja, R., Panda, B. P., Meher, J., Bhattacharyya, P., Dash, D. P., 2014. Mitigation of Iron Toxicity and Iron, Zinc, and Manganese Nutrition of Wetland Rice Cultivars (Oryza sativa L.) Grown in Iron-Toxic Soil. Clean Soil, Air, Water. 42(11):
1604-1609.

Shen, Y., Jin, L., Xiao, P., Lu, Y., Bao, J. 2009. Total phenolics, flavonoids, antioxidant capacity in rice grain and their relations to grain color, size and weight. Journal of Cereal Science. 49: 106-111.

Singleton, V. L., Orthofer, R., LamuelaRaventos, R. M. 1999. Analysis of total phenols and other oxidation substrates and antioxidants by means of FolinCiocalteu reagent. Meth. Enzymol. 299: 152-178.

Sompong, R., Siebenhandl-Ehn, S., Linsberger-Martin, G., Berghofer, E. 2011. Physicochemical and antioxidant properties of red and black rice varieties from Thailand, China and Sri Lanka. Food Chem. 124(1): 132-140.

Tan, F., Dai, W. and Hsu, K. 2009. Changes in Gelatinization and Rheological Characteristics of Japonica Rice Starch Induced by Pressure/Heat Combinations. Journal of Cereal Science. 49(2): 285-289.

Tavares, K. A. C., Zanatta, E., Zavareze, D., Helbig, E., Diaz, G. A. R. 2010. The Effects of Acid and Oxidative Modification on the Expansion Properties of Rice Flours with Varying Levels of Amylose. Food Science and Technology. 43(8): 1213-1219.

Wu, S. J. and Ng, L.T. 2008. Antioxidant and free radical scavenging activities of wild bitter melon (Momordica charantia Linn. var. abbreviateSer.) in Taiwan. LWT-Food Sci. Technol. 41: 323-330.

Yawadio, R., Tanimori, S., Morita, N. 2007. Identification of phenolic compounds isolated from pigmented rices and their aldose reductase inhibitory activities. Food Chemistry. 101(4): 1616-1625.

Yodmanee, S., Karrila, T. T. and Pakdeechanuan, P. 2011. Physical, chemical and antioxidant properties of 
pigmented rice grown in Southern Thailand. International Food Research Journal, 18(3): 901-906.

Zeng, F., Ali, S., Zhang, H., Ouyang, Y., Qiu, B., Wu, F. and Zhang, G. 2011. The influence of $\mathrm{pH}$ and organic matter content in paddy soil on heavy metal availability and their uptake by rice plants. Environmental Pollution. 159:
84-91.

Zhang, Y. L., Xu, M. H., Zeng, Y. W., Yao, C. X. and Chen, S. N. 2007. Relationship between the First Base of the Donor Splice Site of Waxy Gene Intron 1 and Amylose Content in Yunnan Indigenous Rice Varieties. Rice Science. 3: 189-194.

\section{How to cite this article:}

Tiluttama Mudoi and Priyanka Das. 2019. A Study on Phytochemicals and Mineral Content of Indigenous Red Rice of Assam, India. Int.J.Curr.Microbiol.App.Sci. 8(04): 1-12. doi: https://doi.org/10.20546/ijcmas.2019.804.001 